\title{
Compatibilization Potential of Ionic Liquid-Based Surfactants for Polymer Blends
}

\author{
Ahmad AdlieShamsuri* \\ Laboratory of Biocomposite Technology, Institute of Tropical Forestry and Forest Products, University Putra Malaysia, Malaysia \\ Submission: July 6, 2018; Published: July 10, 2018 \\ *Corresponding author: Ahmad AdlieShamsuri, Laboratory of Biocomposite Technology, Institute of Tropical Forestry and Forest Products, \\ University Putra Malaysia, Malaysia; Email: adlie@upm.edu.my
}

Keywords: Surfactant; Ionic liquid; Compatibilizer; Polymer blend; Hydrophobic; Biopolymer

Abbrevations: ILs: Ionic Liquids; ILBS: Ionic Liquid-Based Surfactants

\section{Opinion}

The development of the polymer composites industry has been very encouraging in the past years. The polymer blends have also been received considerable attention, this is due to the blends are easy to prepare, their production cost is low, and so on. At the present time, bioplastics such as polylactic acid, polyhydroxybutyrate and polybutylene succinate are gaining consideration due to their excellent biodegradability, biocompatibility and non-toxicity. Blend between bioplastics and biopolymers (for example; cellulose, zein and starch) to produce bioplastic/biopolymer blends have attracted the researchers' interest. Besides, the produced bioplastic/biopolymer blends may also be able to be used in fabrication of biocompatible and biodegradable products. Moreover, the utilization of expensive synthetic bioplastics can be reduced through consumption of biopolymers this can further lower the cost of products $[1,2]$.

Nevertheless, the blend approach suffers from low physicochemical properties due to incompatibility in the blends system. The compatibility between the bioplastic and biopolymer is very low, thus results in reductions of their performance, particularly in the mechanical, thermal and rheological properties. The incompatibility is due to the bioplastic which wholly non-polar (hydrophobic) [3], while the biopolymer is naturally polar (hydrophilic) [4], and therefore the importance of compatibilization on the blends could not be ignored.

In response to this, the compatibilization methods by using compatibilizers were frequently carried out to compatibilize between two different polymers particularly for a better adhesion at their interface [5]. Previous reports have indicated that the organic salts such as surface-active agents (surfactants) could also be used as compatibilizers in polymeric blend and composite systems specifically for non-polar and polar polymers [6-8]. This is due to the fact that the surfactants have amphiphilic character which contained of non-polar and polar parts (hydrophobic and hydrophilic groups) $[9,10]$ that capable to compatibilize between non-polar and polar polymers [11]. Thus, they could provide compatibility between the component phases of bioplastic and biopolymer in the blends system.

On the other hand, ionic liquids (ILs) are known as organic salts that have low melting temperature $\left(<100^{\circ} \mathrm{C}\right)$. ILs are nonvolatile, highly polar and stable, miscible and soluble with many organic and/or inorganic compounds, chemically inert as well. ILs are also non-toxic, recyclable, non-flammable and ecofriendly [12]. The use of ionic liquid-based surfactants (ILBS) for compatibilization seems to be remarkable because they have fascinating feature i.e. low melting temperature compared to ordinary surfactants, this could increase the compatibilization efficiency.

Additionally, among several types of ILBS, 1-dodecyl3-methylimidazolium-based ILs can be employed for experimentation since they have some valuable characters for instance; consisted of single long alkyl chain (effective for the hydrophobic-hydrophobic interaction), environmentally friendly, low melting temperature, low toxicity and most importantly they are also thermally stable.

It is expected that the ILBS will improve the physicochemical properties (mechanical, thermal, rheological, etc.) of the polymer blends since they have amphiphilic character which can act as interaction link between non-polar (hydrophobic) and polar (hydrophilic) polymers, and they can assist them to interact with each other as well. It is also anticipated to benefit the industries 
that are interested to utilize both bioplastics and biopolymers in their products because this approach does not require any modifications of the polymers.

\section{References}

1. Chidambarampadmavathy K, Karthikeyan OP, Heimann K (2017) Sustainable bio-plastic production through landfill methane recycling. Renew Sust Energ Rev 71: 555-562.

2. Kulshrestha N, Gupta PN (2016) Structural and electrical characterizations of 50: 50 PVA: starch blend complexed with ammonium thiocyanate. Ionics 22(5): 671-681.

3. Frollini E, Bartolucci N, Sisti L, Celli A (2015) Biocomposites based on poly (butylene succinate) and curaua: mechanical and morphological properties. Polym Test 45: 168-173.

4. Samper-Madrigal MD, Fenollar O, Dominici F, Balart R, Kenny JM (2015) The effect of sepiolite on the compatibilization of polyethylenethermoplastic starch blends for environmentally friendly films. J Mater Sci 50(2): 863-872.

5. Chen X, Zhou L, Pan X, Hu J, Hu Y, et al. (2016) Effect of different compatibilizers on the mechanical and thermal properties of starch/ polypropylene blends. J Appl Polym Sci 133(17): 43332.
6. Shamsuri AA, Daik R, Ahmad I, Jumali MHH (2009) Nylon-6/liquid natural rubber blends prepared via emulsion dispersion. J Polym Res 16(4): 381-387.

7. Sudari AK, Shamsuri AA, Zainudin ES, Tahir PM (2017) Exploration on compatibilizing effect of nonionic, anionic, and cationic surfactants on mechanical, morphological, and chemical properties of high-density polyethylene/low-density polyethylene/cellulose biocomposites. I Thermoplast Compos 30(6): 855-884.

8. Shamsuri AA, Daik R, Zainudin ES, Tahir PM (2014) Compatibilization of HDPE/agar biocomposites with eutectic-based ionic liquid containing surfactant. J Reinf Plast Comp 33(5): 440-453.

9. De S, Malik S, Ghosh A, Saha R, Saha B (2015) A review on natural surfactants. RSC Adv 5(81): 65757-65767.

10. Dzulkefly K, Khoh HF, Ahmad FBH, Adlie Ahmad S, Lim WH (2010) Solvent-free esterification process for the synthesis of glucose bolaform surfactants. Oriental J Chem 26(3): 747-752.

11. Shamsuri AA, Azid MKA, Ariff AHM, Sudari AK (2014) Influence of surface treatment on tensile properties of low-density polyethylene/ cellulose woven biocomposites: a preliminary study. Polymers 6(9): $2345-2356$

12. Shamsuri AA, Dzulkefly KA (2011) Synthesizing of ionic liquids from different chemical reactions. Singap J Sci Res 1(3): 246-252.

\section{Your next submission with Juniper Publishers} will reach you the below assets

- Quality Editorial service

- Swift Peer Review

- Reprints availability

- E-prints Service

- Manuscript Podcast for convenient understanding

- Global attainment for your research

- Manuscript accessibility in different formats

( Pdf, E-pub, Full Text, Audio)

- Unceasing customer service

Track the below URL for one-step submission https://juniperpublishers.com/online-submission.php 